Article

\title{
Architect, Catalyst, Advocate, and Prophet: A Four-Lens View of Companies to Support Ecodesign Integration
}

\author{
Raphaëlle Stewart 1,2,*(D), Faheem Ali ${ }^{1,2}$, Casper Boks ${ }^{2}$ and Niki Bey ${ }^{1}$ \\ 1 Division for Quantitative Sustainability Assessment, Department of Management Engineering, \\ Technical University of Denmark, Diplomvej, Bygning 371, 2800 Kongens Lyngby, Denmark; \\ faheem.ali@ntnu.no (F.A.); niki@dtu.dk (N.B.) \\ 2 Department of Design, Norwegian University of Science and Technology, Kolbjørn Hejes Vei 2b, \\ 7491 Trondheim, Norway; casper.boks@ntnu.no \\ * Correspondence: rste@dtu.dk or raphaels@stud.ntnu.no; Tel.: +45-4525-1642
}

Received: 28 August 2018; Accepted: 23 September 2018; Published: 26 September 2018

\begin{abstract}
Companies are increasingly expected to develop products with better environmental performance throughout their life cycle. Academic literature on ecodesign integration, which investigates firms' practices of dealing with environmental concerns associated with their products, indicates a need for more focus on formal and informal organizational aspects. From the general management literature, the four-lens view of organizations provides a rich understanding of organizations by embracing their formal (structural lens) and informal (human, political and symbolic lenses) functioning. This article aims to explore the extent to which the four-lens view may support ecodesign integration in companies. This exploratory study builds on fifteen interviews about ecodesign integration at seven manufacturing companies in Denmark and Norway. The main results are threefold: (i) the different lenses of organizations could be found in measures mentioned at the case companies; (ii) measures from the architect's perspective seemed necessary to provide an official scene for ecodesign and help prioritizing it in organizations; and (iii) the catalyst's, advocate's, and prophet's perspectives seemed necessary to facilitate or complement the architect's perspective. In the light of these findings, the four-lens view seems relevant to strengthen ecodesign integration, and its potential use as a reflective tool is an avenue for future work.
\end{abstract}

Keywords: sustainability; ecodesign; product development; product innovation; change; organization; industry; case study; interview; Nordic

\section{Introduction}

As sustainability has become a central topic in our societies, companies are increasingly expected to tackle their environmental sustainability challenges. The product life cycle is a key perspective to address such challenges, as emphasized in academia and recent developments in industry, e.g., update of ISO 14001 environmental management system standard with greater emphasis on products' life cycle environmental impacts [1,2]. Ecodesign is a product-oriented approach defined as "a proactive management approach that integrates environmental considerations in product development and related processes (e.g., purchasing, marketing and research and development) [and] aims to improve environmental performance of products throughout their life cycle" [3]. The market of products labelled as environmentally superior has noticeably been thriving [4,5]. In the EU, regulations such as the Registration, Evaluation, Authorization and Restriction of Chemicals (REACH) regulation and the Restriction of Hazardous Substances (RoHS) directive, as well as the Energy related Products (ErP) and the Waste Electrical and Electronic Equipment (WEEE) directives, respectively require 
the avoidance of substance of concerns (REACH and RoHS), energy efficiency measures (ErP) on e.g., home appliances and motors, and producer extended responsibility measures on electrical and electronic equipment (WEEE) [5]. Nevertheless, there is an urgent call for more radical changes in production and consumption patterns that would enable a transition towards sustainability as stated in UN Sustainable Development Goal 12 [6]. Our current understanding of environmental sustainability implies that environmental sustainability challenges ultimately need to be addressed at a socio-technical level [7]. Such endeavor requires companies, as a key stakeholder, to have a more comprehensive understanding and addressing of environmental concerns in the products and solutions they develop, e.g., by developing environmentally superior product/service systems or designing circular products and business models by intention $[8,9]$. However, empirical studies have shown that companies face challenges to develop and successfully implement proactive ecodesign practices [10-13].

Ecodesign tools, techniques and decision supports have been intensively developed in the past decades; e.g., Rousseaux et al. found more than 600 ecodesign tools in their literature review [14]. However, ecodesign scholars agree that these need to be complemented with a focus on business implementation and management problematics to help advance ecodesign uptake by industry [11,15-18]. In that perspective, scholars have explored how to formally integrate ecodesign aspects in business organizations, e.g., in project management [19-22], at different decision-making levels (operational, tactical and strategic-[18]), in environmental management systems [23], and in business procedures and strategy [11,24]. The ISO 14006 standard provides guidance for the implementation of ecodesign in companies as a management system [25,26]. On the other hand, scholars have highlighted that informal aspects of organizations also influence ecodesign integration in companies [11,17,18,27-29]. Hence, we identify a need for approaches embracing both aspects, i.e., the combination of formal aspects ("structures, processes, systems, etc. which are designed to motivate and facilitate individuals in the performance of organizational tasks" [30] (p. 193)), and informal aspects ("patterns of communication, power, and influences, values and norms which characterize how an organization actually functions" [30] (p. 193)).

In management literature, Bolman and Deal elaborated a four-lens view of organizations which builds on four groups of management theories depicting organizational functioning from different perspectives [31]. In this four-lens view, organizations are viewed on the one hand as formal structures designed to fulfill a given mission, applying specific procedures, systems, and roles (structural lens). On the other hand, firms are informal communities where employees have needs, aspirations, preferences and fears (human lens), personal or group agendas with possibly conflicting objectives (political lens), as well as a shared understanding of "how things work around here" (e.g., habits and routines) (symbolic lens) [31]. The four-lens view underlines that single situations in organizations can be looked at, interpreted, and leveraged from different perspectives offered by the different lenses. In that sense, the four-lens view invites leaders and change agents in organizations to reframe their views of their organization to better understand situations and adopt relevant courses of action.

Within internal stakeholders driving sustainability in organizations, we can distinguish between employees primarily working with environmental management, e.g., a sustainability manager or Environment, Health and Safety specialist, and employees working in core business roles who seek to drive the sustainability agenda based on individual interest [32]. These two types of stakeholders have been found to be central in driving sustainability practices in companies [33-36], and have been expected to drive sustainability integration in their organization as "champions", "change agents" or “leaders" [32,35-39].

Because it provides a framework to approach the richness of organizational functioning with a focus on both formal and informal aspects, and because it may deliver practical support for change agents in organizations, the present study draws on the four-lens view of organizations and aims to answer the following research question: To what extent can the four-lens view of organizations support ecodesign integration at companies? To address this question, first we build on existing academic 
literature to identify the potential relevance of the four-lens view of organizations in the light of common challenges associated with ecodesign integration. Furthermore, we empirically investigate the presence of and relations between the different lenses of organizations in ecodesign integration efforts in industry, with the purpose to further our understanding of a multi-lens approach.

Ecodesign proponents in companies, including both sustainability or environmental management teams and employees from core functions proactively involved in pushing the ecodesign agenda within their organization, are the target audience of our study, together with consultants and scholars working with supporting ecodesign integration in companies. In the remainder of the article, we first elaborate the conceptual framework and link the four-lens view of organizations to existing knowledge of ecodesign integration in academic literature (Section 2). Then we investigate how the four-lens view emerges from ecodesign integration as described in interviews conducted at a set of case companies: Section 3 explains how the empirical evidence was collected and analyzed; the results are presented in Section 4. In Section 5, the findings are discussed in the perspective of earlier work, the research design, and the limitations of the study, before providing concluding remarks and an outlook for future work in Section 6.

\section{Conceptual Framework}

\subsection{Introducing the Four-Lens View of Organizations}

Bolman and Deal's four-lens view of organizations was developed with the aim to bring together different groups of management theories to pragmatically support the work of managers and change agents in organizations [31]. The structural lens (or frame) builds among others on Taylor's scientific management theory [40], Weber's bureaucratic management theory [41], and Mintzberg's work on organizational structures [42]. The human lens is derived among others from the Theory Y (as opposed to Theory X) developed by McGregor [43], and the work of Argyris on the relationships between organizations and individuals [44]. The political lens is anchored among others in the work of Kotter and Pfeffer about political skills of managers [45,46]. The symbolic lens draws among others from the work of Schein on organizational culture [47]. The structural lens emphasizes division and coordination of work and embraces well defined rules, policies and goals; the human lens focuses on the relationships between employees and the organization and pays specific attention to individual needs; the political lens views organizations as arenas where stakeholders compete for power and resources; and the symbolic lens focuses on creating meaning in a chaotic environment [48].

The purpose of the four-lens view is to invite leaders and change agents in organizations to reframe, and hence expand, their views of their organization to gain a deeper understanding of hotspots or challenges and a better overview of available levers. This is done by alternatively using an architect's, catalyst's, advocate's, or prophet's perspective corresponding to different metaphors of organizations. Through the structural lens, the architect views its organization as a machine or a factory and design targets, functions, processes, and coordination mechanisms. Through the human lens, the catalyst views its organization as a family and aims at embracing employees' needs, fears and aspirations and supporting them. Through the political lens, the advocate views its organization as a jungle and aims at building coalitions, gaining power, and negotiating agendas. Through the symbolic lens, the prophet views its organization as a temple and focuses on fostering sense-making, challenging common beliefs and inspiring people. Figure 1 displays the four-lens view of organizations as a conceptual framework which includes for each lens (i) the corresponding metaphor of organization, (ii) the perspective adopted by change agents, (iii) the summary of associated basic assumptions about organizations, and (iv) examples of courses of action, adapted from the work by Bolman and Deal [31,48]. 



PERSPECTIVE ADOPTED BY

THE CHANGE AGENT

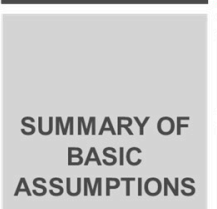

ASSUMPTIONS
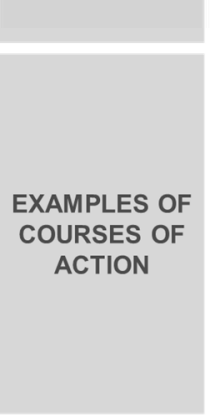
and objectives. divided, defined by clarify policies and procedures budgeting, or control systems units

Plan processes

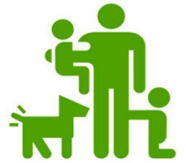

HUMAN

FAMILY
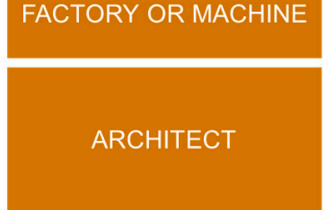

- The organization exists to achieve established goals

- What matters is that tasks are clearly and rationally procedures and coordinated so that work gets done.

- Reorganize, implement or

Develop new information,

Add new organizational

Figure 1. Conceptual framework around the four-lens view of organization, including for each lens (i) the corresponding metaphor of organizations, (ii) the perspective adopted by change agents, (iii) the summary of basic assumptions about organizations, and (iv) examples of associated courses of action, elaborated based on the work by Bolman and Deal [31,48]. Icons from left to right: Architect by Augusto Zamperlini from Noun Project; Family by Luis Prado from Noun Project; Lawyer asking question by Gan Khoon Lay from Noun Project; Hero by Andrew J. Young from Noun Project.

Organizational research scholars have used the four-lens view as a main conceptual framework in empirical studies focusing on four distinct topics. They have investigated (i) change management [49-51], (ii) current organizational situations [52-54], (iii) specific roles or positions [55], and (iv) lens preferences of leaders and managers [48,56-58]. Applicative studies have focused primarily on educational organizations [48-50,58], and to some extent on healthcare organizations $[50,56,57]$. In the first group of studies, the four-lens view has been used to interpret challenges associated with the investigated change, e.g., innovation in higher education [49], implementation of a participatory management approach in a hospital [51] or academic reform in pharmacy [50]. Scholars agreed that using a multi-frame approach enabled deeper understanding of situations and should be used to design relevant solutions and improvements [49-51]. In the second and third group of studies, the model has been used to interpret current challenges, experienced in general in the organization [52,53] or by specific individuals [55]. It was also used to interpret the success factors of a given program [54]. In the last group of studies, the model has been used to explore the use of lenses by managers and leaders in organizations, as well as to study the influence of lenses' use on managerial and leadership effectiveness. For instance, Bolman and Deal used their model to study the extent to which managers, mainly in academic institutions, used different lenses in their approaches, based on analyses of critical incident reports, and how it affected their effectiveness as managers or leaders as perceived by their colleagues, based on a survey [48]. In the analysis 
of critical incident reports, they found that the structural frame was particularly prominent among managers and the symbolic frame, particularly absent. To survey the lenses currently used by managers in their work, Bolman and Deal developed a leadership orientation instrument operationalizing each lens into a set of activities or attitudes [48]. The survey revealed that effective managers were associated with the structural lens, whereas effective leaders were associated with the political and symbolic lenses. The leadership orientation instrument was further used by several scholars for a similar purpose [56-58]. In the context of schools and universities, Thomson found that fully balanced managers, i.e., managers who scored high on all lenses, performed better on all leadership dimensions, than unbalanced managers, i.e., mainly using one or two lenses [58]. In their study of health information program directors, Sasnett and Ross found that the structural and the human frames dominated, to the detriment of the political and symbolic frames [56]. McGowan and Stokes surveyed a sample of Irish physiotherapy managers and also found that the political and symbolic lenses were underused, whereas the structural and human lenses highly used [57]. They further found a correlation between the number of lenses reported as used by managers and higher self-rating of effectiveness as leaders and managers [57].

\subsection{The Four-Lens View of Organizations in the Context of Ecodesign Integration}

Earlier scholars have considered ecodesign integration as an organizational change and built on the change management literature to investigate the phenomenon [28,59]. Ecodesign proponents are expected to play the role of leaders or change agents in their organization. In these perspectives, transposing the four-lens view of organizations to the context of ecodesign integration appears as a meaningful potential approach to support ecodesign proponents in their efforts to strengthen ecodesign integration. Furthermore, the academic literature on ecodesign integration has reported several internal challenges which can interestingly be shown to pertain to the four lenses of organizations as described in the following paragraphs [60].

Through the structural lens, scholars have reported the lack of strategy or concrete goals to integrate environmental aspects in products [17,61-63], the absence of a predefined toolset to support ecodesign decision-making, and the lack of formal presence of ecodesign aspects in project assessment frameworks [19,22], and performance measurement systems [61,63]. Additionally, scholars reported lack of clear responsibility allocation and presence in the organigram [17,39], and the absence of specific mechanisms to collect information related to sustainability from the market and regulation [62]. Scholars have recommended exploring possibilities to integrate ecodesign aspects in existing processes $[11,12,19,21,64-66]$, in order to create an official arena for discussing environmental aspects [65], and investigating how to formally integrate ecodesign aspects in the different levels of organization, i.e., operational, tactical and strategic [18]. The establishment of clear environmental goals for product design is also recommended, as well as the creation of environmental specialist roles to support development processes $[39,64,66]$.

Through the human lens, earlier studies have shed light on the fact that employees in companies may fear work overload associated with ecodesign [28,61], as well as losing flexibility [28]. Some employees may also be highly uncomfortable with the topic $[13,28]$, not aware of the challenges [67], or not capable of addressing them $[12,28,64,67,68]$. Some employees may have high interest, motivation and commitment for ecodesign aspects while others lack one or the three $[12,64]$. Exploring how to best empower employees on sustainability topics and what drives motivation and resistance of/among employees has been suggested as a key enabler to support ecodesign integration $[13,69]$.

Moving on to the political lens, scholars have reported that environmental sustainability aspects may have rather low priority on senior management agendas which mainly focus on short term objectives, mainly lowering costs, and do not see environmental concerns as major risks since market and regulation drive is perceived as low $[13,62,68]$. It has also been indicated that project teams may struggle to secure resources for ecodesign activities [13], or translate environmental information into 
information useful for the business and possible to integrate in a business case that senior management could be interested in [12,62]. Maintaining consistent support from management for ecodesign aspects over time is also a reported challenge $[13,16]$. Because people have different agendas and areas of interest, due to their position in the company, they may value information differently. Hence, concretely it may be the case that employees observe some trends regarding environmental sustainability concerns of customers but do not pass them on further in the organizations [70]. In response, it has been recommended for instance to review key performance indicators of the people who need to be convinced for environmentally preferable solutions to be pushed for, and to adapt communication strategies accordingly [71].

Finally, through the symbolic lens, earlier studies have reported resistance to ecodesign integration pertaining to general beliefs such as "sustainability is not my responsibility", "sustainability is not invented here" [28], "sustainability is a distraction" [61], or "sustainable options lead to costly or poor quality products" [13]. Common understanding around what sustainability means for the business may be lacking [72]. The needs for a new "mindset emphasizing the importance of the environmental considerations" [64] (p. 103), or for a different "storytelling" around environmental aspects closer to the company's reality have been evoked [13]. Skelton et al. reported that although environmental specialists are listened to by project teams, they may remain considered by the latter as very much outside the project community which limits their influence on projects [29]. The use of rituals, e.g., a dismantling event taking place every year to build awareness about the end-of-life of developed products [29], may be leveraged through the symbolic lens.

Hence, existing knowledge of ecodesign integration indicates the potential relevance of the four-lens view of organizations to support ecodesign proponents in their efforts to strengthen ecodesign integration in their company. The following sections explore how the four-lens view can be addressed in a consistent manner and further translated into the ecodesign integration context with learnings from empirical data.

\section{Methodology}

An overview of the methodological approach adopted in this study is displayed in Figure 2. The following sections provide detailed descriptions of data collection and data analysis.

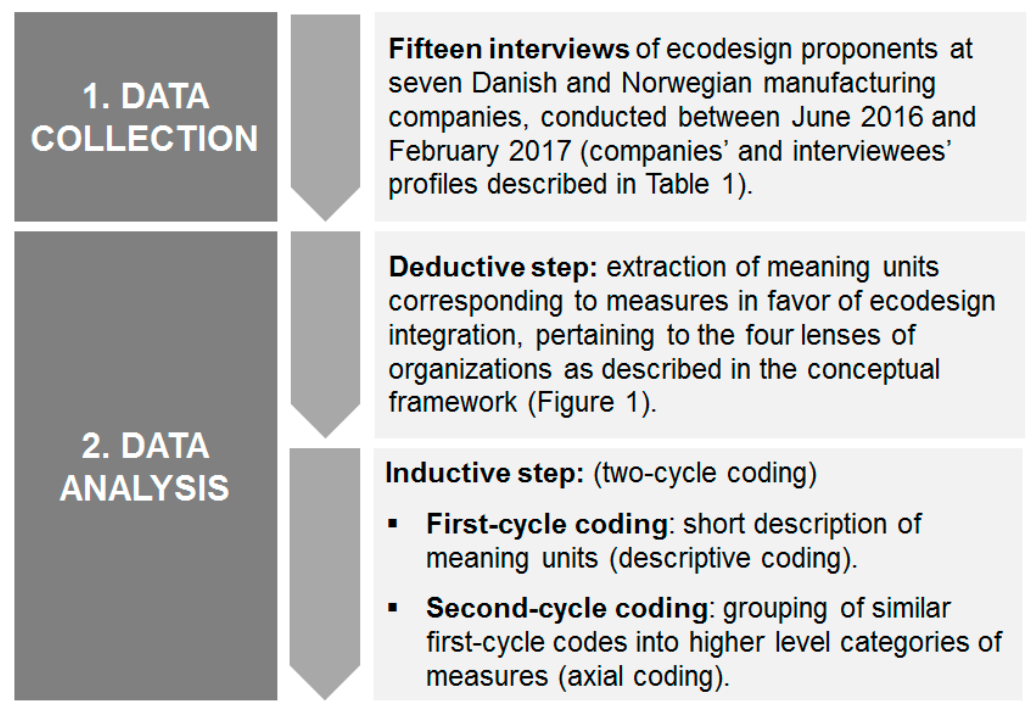

Data triangulation: Internal documents (e.g. checklist) and most recent corporate sustainability reports (released in 2016).

Validity: Use of an existing conceptual framework from general management literature and linkage with earlier academic knowledge on ecodesign integration.

Reliability: Revision by the coauthors of randomly selected coded units (covering $75 \%$ of total data) and adjustment of initial codes in case of disagreements between coders (the results are displayed in Table A1).

Figure 2. Overview of the methodological approach. 


\subsection{Data Collection}

The empirical basis of the present study consists of a set of fifteen interviews at a sample of seven case companies in the Danish and Norwegian manufacturing sector. There is no specifically recommended number of cases in case study research, but four to ten cases are typically targeted [73]. Earlier empirical studies of ecodesign integration in companies have typically included four to twelve case companies and most studies have involved two or three interviewees per case company $[12,13,27,62,63,66,67,74-76]$. Manufacturing companies were of particular interest for the present study because they are key players in designing and manufacturing products [77]. Moreover, there are indications that the manufacturing sector has a stronger focus on life cycle thinking than the service sector $[78,79]$. The selection of case companies is based on convenient sampling, i.e., based on previous or new established contact with companies, and on a set of criteria, namely (i) headquartered in the Nordics, (ii) manufacturing companies with in-house product development, and (iii) presence of a sustainability strategy. The case companies are large organizations, with all but one (which is not stock exchange listed) included in the Dow Jones Sustainability Index (DJSI). From this perspective, the set of cases presents characteristics of homogenous sampling, but also characteristics of variation sampling because the case companies were at different steps of their sustainability journey and belong to different industrial sectors [80].

Lasting between 60 and $90 \mathrm{~min}$, two authors of the present article conducted the fifteen interviews between June 2016 and February 2017. The details about the interviewees' profiles are displayed in Table 1. The set of interviewees includes two types of ecodesign proponents. The first type includes employees working in sustainability-related functions, e.g., sustainability managers or Environment, Health and Safety specialists, and the second type includes employees involved in product development with personal interest in pushing the ecodesign agenda. Interviews were semi-structured and designed to further the knowledge about ecodesign integration in companies, based on a review of existing academic knowledge of the topic. The interview focus was on (i) investigating how ecodesign practices have been and are being integrated in the organization and (ii) exploring internal (across departments) and external (in the business ecosystem, e.g., with suppliers and customers) interactions around ecodesign at the company. The themes addressed during interviews are provided in Appendix A. In the present study, the interview transcripts are thus used as a secondary data source to explore the presence of the different lenses of organizations in ecodesign proponents' elaborations about ecodesign integration at their company.

Internal documentation provided by the case companies (e.g., stage gate model used by the company in product development projects, ecodesign checklist and ecodesign tool) and their most recent corporate sustainability report (released in 2016) were used as complementary data source and enabled some extents of data triangulation. Corporate sustainability reports were particularly suited to grasp the overall sustainability context at each case company and in order to elicit companies' sustainability vision, drivers (e.g., presence of a market for ecodesigned products), strategy (e.g., reducing the life cycle environmental impacts of products) and targets (e.g., reducing greenhouse gas emissions in the product portfolio, reaching a certain percentage of recycled material in packaging and phasing out substances of concern), in relation to the architect's perspective. However, corporate sustainability reports provide poor inputs on other organizational aspects associated with sustainability integration [81]. 
Table 1. Interviewed case companies, sectors of activity, number of interviews conducted and interviewees' job area. EHS = Environment, Health and Safety; CR = Corporate Responsibility; R\&D = Research and Development.

\begin{tabular}{cccc}
\hline Company & Sector & Number of Interviews & Interviewees' Job Area \\
\hline Company A & Medicare & 2 & $\begin{array}{c}\text { A1: EHS } \\
\text { A2: EHS }\end{array}$ \\
\hline Company B & Biotechnologies & $1^{*}$ & B1: Sustainability \\
\hline Company C & Energy & 2 & $\begin{array}{c}\text { C1: EHS } \\
\text { C2: EHS }\end{array}$ \\
\hline Company D & Construction & 2 & $\begin{array}{c}\text { D1: Regulation (incl. environment) } \\
\text { D2: Sourcing and technologies }\end{array}$ \\
\hline Company E & Consumer products & 2 & $\begin{array}{c}\text { E1: EHS } \\
\text { E2: CR }\end{array}$ \\
\hline Company F & Consumer products & 2 & F1: Communication \\
F2: Sourcing
\end{tabular}

* Information about ecodesign activities collected at a university lecture given the same year by another sustainability expert of the same company was also included in the analysis.

\subsection{Data Analysis}

The unit of analysis, defined as the phenomenon under study [82], is ecodesign integration at each case company, including all activities which aim at bringing environmental considerations in the company's products. To address the research question, we analyzed the interview data with the two following objectives: (i) exploring the presence of the different lenses of organizations in descriptions about ecodesign integration at the case companies, and (ii) gathering indications of relations between the different lenses of organizations.

To explore the presence of the different lenses, we analyzed each interview transcript using a deductive-inductive content analysis method [83]. The deductive step consisted of identifying "meaning units" (or coded units) corresponding to measures stemming from the different lenses of organizations. Meaning units are defined as "words, sentences or paragraphs containing aspects related to each other through their content and context" [84]. In our case, sentences or paragraphs were manually unitized from the transcripts as meaning units based on thorough reading of interview transcripts. An example of meaning unit is the following extract "Stage gate is the normal process. And life cycle assessment is part of the stage gate project. And we use the stage gate model in development projects, for all new products actually". A "measure" was broadly defined as an action or solution indicated by the interviewees as happening or necessary to facilitate ecodesign integration. The deductive coding of meaning units with respect to the four lenses of organizations was based on the conceptual framework derived in Section 2, see Figure 1. The meaning units were stored in a spreadsheet for the second (inductive) step of the analysis. In the inductive step, we coded the extracted meaning units, using a two-cycle coding approach, as suggested by Saldaña [85]. The first-cycle coding phase consisted of descriptive coding, i.e., associating each meaning unit with a short phrase summarizing the described measure [85]. For the example of meaning unit mentioned above, the first-cycle code we chose is "Life cycle assessment is used as part of the product development process". The second-cycle coding phase consisted of grouping the first-cycle codes into higher-level categories of measures using an axial coding approach, i.e., seeking to group together codes that had been split in the first-cycle coding but were then considered to reflect similar aspects [85]. For the example of meaning unit mentioned above, the second-cycle code we chose is "Integrate ecodesign procedure in product development 
process". To explore the relations between the different lenses of organizations in supporting ecodesign integration, instances where they could be found to interact with each other were analyzed.

To ensure the quality of the analysis, we followed the guidelines provided by Riege [86]. Validity was enhanced by anchoring the findings in a conceptual framework derived from management literature and comparing the results with insights from the ecodesign integration literature. The use of the four-lens view to conduct content analysis was found challenging by Bajis et al. who reported initial overlaps between each lens [50]. This aspect pertains to the reliability criterion and was addressed in the present study through the recording and transcribing of the interviews and through involving multiple researchers in the data analysis [86]. The full coding process was initially performed by one author (the main coder). Seventy-five percent of the coded units were randomly selected for a revision by the co-authors. The selection was designed to respect the proportions of coded units for each case company, e.g., a total number of 100 coded units for one case company would lead to 75 randomly selected coded units for the revision. The selected coded units were then divided into three parts and checked by the co-authors against (i) the lens of organization the coded unit was considered to relate to, and (ii) the choice of second-cycle coding. The division was done so that one co-author would review the full set of selected coded units corresponding to a given case company, to build an overview of that case company. The revision and associated discussion led to slight changes in the coding results (see Table A1 in Appendix B) and wording chosen for second-cycle codes. The most challenging part of the coding was the deductive phase consisting of associating measures for ecodesign integration to an underlying lens of organization. The team agreed that to conduct such exercise, the coder should rely on the basic assumptions of what an organization is, as displayed in Figure 1, which are implicitly present in the interviewee's explanation. Illustrative quotes inserted in the following sections are extracted from the interview transcripts. They were corrected for grammar errors, false starts and filler words, as well as neutralized, e.g., by removing references to country markets or specific materials, so that neither the case companies nor the interviewees could be recognized [87].

\section{Results}

\subsection{Mapping of Measures for Ecodesign Integration in the Four-Lens View}

Table 2 shows for each case company and lens of organizations the identified measures resulting from the second-cycle coding phase. The distribution of coded units in the different perspectives of organizations is shown in Table A2 and examples of first-cycle coding phrases associated with second-cycle coding categories are given in Table A3. We make a difference between the measures indicated as currently happening at least to some extent in the company (i.e., established for the architect's perspective or leveraged approaches for catalyst's, advocate's, or prophet's perspectives), and the measures identified as lacking and needed. However, the distinction is not in focus in the present study which concentrates on measures as levers for ecodesign integration, rather than measures being practiced. Our findings indicate that for most case companies, measures stemming from the architect's, catalyst's, advocate's, and prophet's perspectives were present in discussions about facilitating ecodesign integration within the organization. Most frequent measures (both happening and lacking ones) across case companies include "integrate ecodesign procedure in product development process", "acquire/develop tools for decision-making", "design strategy related to products" and "set direction/target/goals" (architect's perspective); "support/chaperon initiatives" (catalyst's perspective); "align with business/stakeholders' agenda", and "negotiate for prioritization" (advocate's perspective); and "manage beliefs/"truths" in the company" (prophet's perspective). 
Table 2. Results from the second-cycle coding. For each lens, mentioned measures in favor of ecodesign integration are mapped against the case companies. $\mathrm{H}=$ indicated as happening at least to some extent in the organization; $\mathrm{N}=$ indicated as lacking and needed.

\begin{tabular}{|c|c|c|c|c|c|c|c|c|}
\hline MEASURES & $\begin{array}{l}\varangle \\
\vec{\Xi} \\
\text { है } \\
\text { है }\end{array}$ & $\begin{array}{l}\infty \\
\vec{\Xi} \\
\text { : } \\
\text { : } \\
0\end{array}$ & 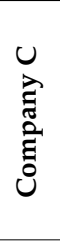 & 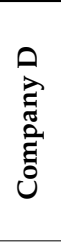 & 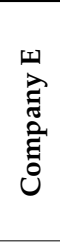 & 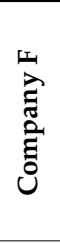 & 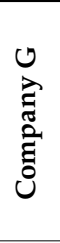 & 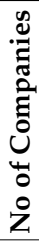 \\
\hline \multicolumn{9}{|l|}{ Architect's perspective } \\
\hline Integrate ecodesign procedure in product development process & $\mathrm{H}$ & $\mathrm{H}$ & $\mathrm{H}$ & $\mathrm{H}$ & $\mathrm{N}$ & $\mathrm{N}$ & $\mathrm{N}$ & 7 \\
\hline Acquire/develop tools for decision-making & $\mathrm{H}$ & $\mathrm{H}$ & $\mathrm{H}$ & $\mathrm{H}$ & $\mathrm{H}$ & & $\mathrm{H}$ & 6 \\
\hline Design strategy related to products & & $\mathrm{H}$ & $\mathrm{H}$ & $\mathrm{N}$ & $\mathrm{N}$ & & $\mathrm{N}$ & 5 \\
\hline Set directions/goals/targets & & $\mathrm{H}$ & & $\mathrm{N}$ & $\mathrm{N}$ & $\mathrm{N}$ & $\mathrm{N}$ & 5 \\
\hline Develop guidelines related to product development & & & & & $\mathrm{H}$ & $\mathrm{H}$ & & 2 \\
\hline Formally define "sustainability" (e.g., standard, criteria) & & & & $\mathrm{H}$ & & $\mathrm{N}$ & & 2 \\
\hline $\begin{array}{l}\text { Translate strategy into action plan for specific business } \\
\text { units/functions }\end{array}$ & & & & & $\mathrm{H}$ & & $\mathrm{N}$ & 2 \\
\hline $\begin{array}{l}\text { Translate corporate targets into targets for individual } \\
\text { innovation projects }\end{array}$ & & $\mathrm{N}$ & & & & & & 1 \\
\hline Create sustainability roles & & & & $\mathrm{H}$ & & & & 1 \\
\hline Set up new KPIs & & & & & $\mathrm{H}$ & & & 1 \\
\hline Use a process with more experimental approach & & & & & & & $\mathrm{H}$ & 1 \\
\hline \multicolumn{9}{|l|}{ Catalyst's perspective } \\
\hline Support/chaperon initiatives & $\mathrm{H}$ & & $\mathrm{H}$ & $\mathrm{H}$ & $\mathrm{H}$ & & & 4 \\
\hline Increase comfort of people to work with the topic of ecodesign & & $\mathrm{N}$ & $\mathrm{H}$ & & $\mathrm{H}$ & & & 3 \\
\hline Build individual awareness of impact of decisions & $\mathrm{H}$ & & & $\mathrm{N}$ & & & & 2 \\
\hline Leverage people's aspirations & $\mathrm{H}$ & & $\mathrm{H}$ & & & & & 2 \\
\hline $\begin{array}{l}\text { Participative approach to adapt the product } \\
\text { development process }\end{array}$ & & $\mathrm{H}$ & $\mathrm{H}$ & & & & & 2 \\
\hline Frame ecodesign challenges in familiar terms & & & $\mathrm{H}$ & & & & & 1 \\
\hline Give autonomy & & & & & $\mathrm{H}$ & & & 1 \\
\hline Trigger people/"plant seeds" & $\mathrm{H}$ & & & & & & & 1 \\
\hline \multicolumn{9}{|l|}{ Advocate's perspective } \\
\hline Align with business/stakeholders' agenda & $\mathrm{H}$ & $\mathrm{H}$ & $\mathrm{H}$ & & $\mathrm{H}$ & $\mathrm{H}$ & $\mathrm{N}$ & 6 \\
\hline Negotiate prioritization of ecodesign in agendas & $\mathrm{N}$ & & & $\mathrm{H}$ & $\mathrm{H}$ & & $\mathrm{N}$ & 4 \\
\hline Emphasize criticality/emergency for business & $\mathrm{N}$ & & & $\mathrm{H}$ & $\mathrm{H}$ & & & 3 \\
\hline Target efforts/"pick battles" & $\mathrm{H}$ & $\mathrm{H}$ & & & & & $\mathrm{H}$ & 3 \\
\hline Ally with/get support from relevant people in the company & $\mathrm{N}$ & & & & & $\mathrm{H}$ & & 2 \\
\hline Have answers to all technical questions & & & $\mathrm{H}$ & $\mathrm{H}$ & & & & 2 \\
\hline Leverage network in the company & & & $\mathrm{H}$ & & $\mathrm{H}$ & & & 2 \\
\hline $\begin{array}{c}\text { Secure present resource allocation for long term/more } \\
\text { prospective objectives }\end{array}$ & $\mathrm{N}$ & & & & & & $\mathrm{N}$ & 2 \\
\hline Leverage existing umbrella projects & & & $\mathrm{H}$ & & & & & 1 \\
\hline \multicolumn{9}{|l|}{ Prophet's perspective } \\
\hline Manage beliefs/"truths" in the company & $\mathrm{H}$ & & $\mathrm{H}$ & $\mathrm{H}$ & & & $\mathrm{N}$ & 4 \\
\hline Change perceived vision/mission of the company & & & & $\mathrm{N}$ & & & $\mathrm{N}$ & 2 \\
\hline Leverage "typical ways of doing" & $\mathrm{H}$ & & & $\mathrm{H}$ & & & & 2 \\
\hline Preach in the company & $\mathrm{H}$ & & & $\mathrm{H}$ & & & & 2 \\
\hline Provide inspiration from outside & & & & & & $\mathrm{H}$ & $\mathrm{H}$ & 2 \\
\hline
\end{tabular}

\subsection{The Architect's Perspective}

Within the sample of case companies, some had rather formalized integration of environmental aspects in product development through e.g., the systematic conduction of environmental assessments, whereas others had lesser formal integration in their product development processes. In all case companies, the role of formal integration of environmental aspects in product development processes or strategy in facilitating ecodesign integration was emphasized. At Company A, formal integration is established through the systematic conduction by environmental specialists of a life cycle assessment (LCA) summarized in a brief report using simple color coding to support each product development 
project. There, the latter measure was described as an enabler for ecodesign integration, because it makes it normal to look at environmental criteria in product development.

"And, they listen and they use it also as a part of their decision. They may not do it as I recommend, but that is also because there are so many other criteria for the new product they look into. But they do listen and look into my inputs. [ ... ] it is closely embedded in each stage. They cannot just skip it, if they think it is not relevant." (Interviewee A2)

At Company B, the presence of a top-down strategy for developing sustainable products was presented as an enabler for ecodesign integration, because it leads to higher prioritization in agendas.

"If it is not top-down, it is really hard. It is really hard to go bottom up, I can tell you from experience. Of course you can try to push in the doors, but without management commitment ... [ ... ] So, if you are not being told that this is your target and this is your agenda, you need to make sure that you develop some sustainable product or you engage customer on these topics, you won't prioritize it." (Interviewee B1)

The case companies where formal integration of environmental aspects in product development processes was described as lacking, or only partly in place, indicated that more formal integration was necessary to support ecodesign. At Company D, LCA models were indicated to be available for all products but a lack of systematic use by project teams was mentioned, and more emphasis on using such tools in product development projects was suggested as a way forward. Furthermore, the interviewee indicated a current effort in the organization to design a tool to assess material environmental sustainability performance to establish a currently missing common language around sustainability. At Company E, F and G, the need to formally integrate environmental aspects in processes and systems was highlighted by most interviewees. Interviewees E1 and F1 highlighted the need for guidelines to channel efforts in the organization.

"I think, it's working okay so far and towards the targets we have set, I think it's working okay. But if we want to take a larger step, it should probably be more guidelines and support from central to be able to take a larger step." (Interviewee E1)

"What we want to do is a sort of 4-5 guidelines that you should always consider in an innovation process or communication or other things, you always consider that. [ ... ] So it has been more ad hoc in the way we have introduced these subjects, but what I really believe in is that we have to write a lot of these. You don't succeed in doing it, if you don't have it as part of the structure. What kind of questions should you ask when you [approach] this kind of product? Yes, you should ask these, these and these questions and those sustainable questions [... ] And I think that natural or routine guidelines on that level are important, if not, it is more accidental. [ ... ] So again, I believe more in guidelines and structure. Otherwise, it is going to be, like I think this is a good idea and this one is a good idea etc. But I think it should be part of the whole structure." (Interviewee F1)

Interviewee G2 emphasized the need for a strategic approach and dedicated budget so that solutions can be developed by teams to achieve tangible goals.

"I think that it is number one to have a good strategic approach to it and handle sustainability in the way you would handle other elements of your business. Plan for it, give it a budget, not an economic budget, but a sustainable budget saying that we need to reduce this and this. And then track it. So it is easy for us also to promote good solutions, because then you have a reason when you launch something that is recyclable, then you reduce the footprint. This then, you can use in your work in achieving the strategic goals. So I think we are in a little slow or this is very early for us to be ... so we need hopefully to have more of this." (Interviewee G2)

Interviewee G1 argued that specific ecodesign tools should be included systematically in all innovation projects. 
"We need to be much clearer on what we mean in our innovation work, how we take it in on board or what kind of tools we need to implement in our projects. It should not be a question about if it is a sustainable or ecodesign project. It should be included into every single project." (Interviewee G1)

The need for solutions from the architect's perspective was put forth by one interviewee at Company $\mathrm{G}$ when describing a measure stemming from the advocate's perspective, namely identifying low-hanging fruit, and suggesting targeted actions to reduce the carbon footprint of a set of products, because the latter was considered tedious without the support of architect's measures.

"I had the initiative to develop $\mathrm{CO}_{2}$ calculations for 8 case projects to try to figure or to map out which elements with the products have the biggest influence, which projects have the lowest hanging fruits you can tackle. And that was an initiative that was not from the management, so it was tough for us, because you needed to have sustainability anchored or embedded with the management team. Or else you will have hard time to getting it through the system, getting the funds and things like that. So, this was an initiative which I hope would give a lot of options further down the road." (Interviewee G2)

At Company $\mathrm{C}$, there was an ongoing discussion about integrating LCA as a tool in the product development process, the latter being expected to create an entry point for product developers to get closer to LCAs.

"That is where we are in the process of making an official process for the LCA and then the hope is that traditionally, when we have a new procedure, you have a group of people that review the document and then it is associated with an implementation plan. And the goal of this will be to ... Actually, in our EHS plans, we have traditionally EHS reviewers, and the goal with the LCA procedure is not to have actually EHS reviewers but to have reviewers from the product development and the sales functions. And that will be to somehow act as an introduction and then we will take some communications" (Interviewee C1)

Interestingly, setting environmental targets for products was mentioned as a non-taken measure at Company A and Company C. At Company A, the reported foremost priority of the company is to provide solutions to people who need medical support in their daily life and environment-friendly solutions are weakly driven by the market. Hence, improving the environmental performance of new product generations was considered as a nice-to-have but could not be set as a must in projects. At Company $\mathrm{C}$, the interviewees indicated that material and energy efficiency gains from one generation of products to the other were inherently driven by the business and thus no target was defined from an ecodesign perspective. At Company D, one interviewee also highlighted this idea that energy efficiency was core to the business activity, but that targets regarding material recyclability should be developed. Another interviewee at Company D indicated that there was a lack of direction or focus from top management when it comes to taking decisions in favor of material sustainability, which she explained by a lack of pull from the construction market for "green stamped" products.

\subsection{The Catalyst's Perspective}

Interviewees at Company B and Company $\mathrm{C}$ indicated that the formal establishment of ecodesign aspects in the product development process (architect's perspective) had been designed with the participation of stakeholders from product development, which pertains to the catalyst's perspective.

"We developed this procedure and instruction and before then going on into a second review, we brought it into the project management and engineering functions and we sat in workshops with them, trying and testing it out, piloting it and just talking about it, making sense about it to see if it really fits because it was having to align with another process." (Interviewee C1)

At Company A, when commenting on the extent to which environmental criteria were looked at and taken into account by project teams, one interviewee indicated the high dependence on employees' 
(project managers or specialists) own aspirations to push for the ecodesign agenda in projects and hence the importance to assure that employees who are eager to drive the change can be supported. Such observations can be associated with a catalyst's perspective. The importance of identifying and building on employees' aspirations for ecodesign was also indicated at Company C.

"It always comes down to the passion of the project manager or the specialist, when it comes to this area, environment, responsibility in general, yes for sure. So that's a huge difference between one that thinks "this is very important to me", then they will really take care of it and try to get it into the project as long as they can drive it, as far as they can drive it you could say; while others would be more reluctant saying "this is not something that's on my list". [ . . ] what we can do is that we can support the ones that really want to make a difference here, to give them good evidence so they can go and argue." (Interviewee A1)

"And I would also argue, beyond just personal relations it might also be the personal ambitions or the flexibility of the people you approach. Because you could possibly have someone in your personal network that maybe isn't as ambitious or burning about the topic, in that sense. And I just think also the person in this position was also aligned with somehow same interest and excitement in circular economy topics and was aware of that, whereas somebody else wouldn't have been as willing to drive it. I think." (Interviewee C1)

At Company B, the interviewee outlined that increasing the comfort of employees related to using environmental information was key and sought to be achieved through producing "digestible" material but that more training might be necessary to foster higher levels of comfort.

"LCA is a very scientific tool. We try very much to make it easy to communicate, by preparing slideshows and other materials for them that is easy to digest. And maybe what we are lacking is this training to make them comfortable, because level of comfort depends on person to person, whether they are comfortable in bringing the messages that we could give them." (Interviewee B1)

At Company C, one interviewee mentioned that efforts from a catalyst' perspective were deployed to frame environmental challenges into technical problems for engineers, who are very familiar and good at solving this type of problems, to be empowered and work on solutions.

"So I think the technical engineers are really good at doing a lot of stuff, especially if they know where to end, they are good at solving those problems. So I think if you could remove the fuzzy front end and standardize the work flow, say: "I have a [certain type of material] which wastes production and I don't want that", "I can solve that problem". So, at least that is what we are talking about now, trying to set up something where we can reach larger audience from technical side to have these ideas implemented." (Interviewee C2)

\subsection{The Advocate's Perspective}

The advocate's perspective could be identified in different measures for instance regarding deploying targeted efforts (i.e., "picking battles") (e.g., at Company B), emphasizing criticality for the business (e.g., at Company D) and aligning with business/stakeholders' agenda (e.g., at Company G).

"I think we are having the approach, instead of approaching the marketing in general, that we pick out some areas that we focus on. So we try to pick out some specific projects and deep dive into these from a sustainability point of view and leave the rest. So that has been our approach, also to show what we can bring to the table." (Interviewee B1)

"We had a pilot case running in [a certain market country] during the analysis so we were working very closely with them on [circular economy]. And they are one of our main markets in Europe, so also an important market. And that made management listen better. Because it was not, I mean, [the home] market is important to us, but it is a very small market compared to the rest of Europe. So, if 
something happens in [the home market], I think we will survive. But, if something happens in [the other market country], we have to react because it will influence the company." (Interviewee D1)

"I don't have all the knowledge to convince them why this is so correct. So, it is ... knowledge about sustainability and why it is good for your business. I mean why it is good for environment is easy to say. But why is it good for your business. How it can help to increase the profits, for example." (Interviewee G4)

Although environmental aspects were mentioned to be integrated in their product development through the systematic use of an ecodesign procedure as part of the process, Company A had experienced so far rather low demand from the market and regulations in terms of ecodesign No target for product environmental performance is in place in the company, beyond the "rule of thumb" to decrease impacts from one generation of product to the other. It was mentioned that product development teams need for off-the-shelf materials to be used in projects and that the latter must meet very high property requirements. Environmentally preferable materials may not be mature enough to meet these criteria. One interviewee mentioned the need to have senior managers understand environment-related risks for the business in the future and secure resources to conduct research and development activities around new materials that can be both environmentally preferable and meet the high property requirements.

"The big challenge is that there will be an increased demand for sustainability and the challenge is then to find sustainable materials that fulfill the requirements that we have. Because we have so many really specific high demands for the materials, that they are [with a certain product characteristic] and so on. So that's a challenge. And that's where I think some innovation projects could help on that. Because it's not a shelf product we are looking for here we need to develop some new ... [ ... I I think it is more on prioritizing resources for innovation of sustainable materials" (Interviewee A2)

Another example of an advocate's perspective at Company A was associated with the idea of engaging people who are trusted and listened to when it comes to product development topics, to speak up for environmentally preferable solutions. The idea of allying with relevant people in the organization was also indicated at Company F.

"So that's what you need from these guys is that, if we stand up and tell something it would be "yeah okay but you are also the environmental guys, you don't know anything of the business case and you are the tree lovers", more or less, right? Whereas if it is the marketing person saying: "we see this and this and this and by the way we also think from an environmental point of view that we could do like that", then it is more coming from the guys they are used to listening to giving the normal inputs on this." (Interviewee A1)

"I also work with lobbying and mapping stakeholders, so all the time I think about who else I should get support from to help this through. [ ... I I have more experience working with that now, and I tell you that I need to have support from other important persons" (Interviewee F1)

At Company E, new key performance indicators (KPIs) were set up to support the responsible sourcing strategy, yet one interviewee outlined the importance of engaging with sourcing managers to have them actually prioritize these new KPIs in their daily work, which reflects an advocate's perspective. At Company B, sustainability teams developed an assessment tool able to rate product development projects against their ability to deliver on the UN Sustainable Development Goals which is a relevant reference framework for senior management and thus enables negotiating ecodesign projects in terms that make sense for decision-makers. At Company $\mathrm{C}$, an advocate's perspective was required to convince internal stakeholders to use a specific material by answering the concerns of engineers, mainly focused on technical aspects, e.g., material properties. At Company D, a coalition of the sustainability manager and LCA people took an advocate's perspective to broadly engage core business managers in the organization around the topic of circular economy by systematically highlighting criticality to the business through business risks and opportunities associated with it. 


\subsection{The Prophet's Perspective}

Some measures could be found stemming from a prophet's perspective, for instance associated with the idea of "preaching". At Company D, one interviewee mentioned that in their presentations to senior managers, the teams recurrently seek to bring-in sustainability aspects. At Company A, it was indicated that at the beginning of each product development project, which formally includes the conduction and consideration of an environmental assessment in decisions, the interviewee seeks to give a "ten-minute of fame" speech to brief the team about the environmental sustainability challenges associated with products.

"I try to give a speech in a startup project, I ask for 5-10 min, where I deliver the main issues that could be from our yearly environmental report. But it could also be like mass flows. Pointing out the importance and that could be something like that. $\mathrm{Ok}$, we produce so much waste; we produce $\mathrm{CO}_{2}$ from products developed 5-10 years ago. That is because we still produce these products and they still involve waste and so on. So, that is my key point, so we very much like to reduce waste, and energy consumption is important for our whole $\mathrm{CO}_{2}$ account. It is now that we have to do it. And also, as we are still producing products designed and developed even 20 years ago, things that we talked about before about the environmental awareness from our user side, in 20 years they will still use the products that we developed today and in 20 years, they may have a lot of high requirements to use of bio-waste, recycled waste, reduced packaging or so. So, I ask for these 10 min of fame when we start and it is really well taken." (Interviewee A2)

Associated with the idea of having trusted people from the product development community speak up for environmentally preferable solutions, an interviewee at Company A also seemed to indicate the symbolic importance of such people taking the lead on ecodesign topics, aligned with a prophet's perspective.

"If they start telling new stories then that time, I think that management will start softening up as well. It's a question of followers. So we start to get the specialists to dance and at some point, even management will as well." (Interviewee A1)

Changing common believes about products was mentioned at Company $\mathrm{D}$, where false ideas about products are sought to be changed, similarly at Company $\mathrm{C}$ where new truths about products are sought to be established by environmental teams. Changing the common belief that sustainability is necessarily associated with higher costs was also highlighted as a need at Company G. At Company A, efforts are on to change the common beliefs among product development teams that environmental experts can influence product sustainability performance solely by conducting environmental assessments during the product development process. This reveals that the establishment of a procedure formally bringing environmental aspects in the product development process may not be sufficient to push the ecodesign agenda in the organization. The idea of leveraging "what works best" in terms of communication in the organization was reported at Company A and Company D, also stemming from the prophet's perspective.

"I mean the core of our traditions and values is to have something you have you can feel, touch, hear or see. That is always better than a long report. So we tried to do it better and as concrete as possible. And based on that, we had a pilot case running in [a certain market country] during the analysis so we were working very closely with them on this." (Interviewee D1)

\subsection{Indications of Relations between the Different Lenses of Organizations}

In several cases, measures from an advocate's, catalyst's or prophet's perspective seemed to develop in the absence of an architect's approach at the company. For instance, Interviewee F1 reported that, so far, the inclusion of environmental criteria in product development had been "mostly about convincing the right people" (advocate's perspective). At Company E, both interviewees indicated the 
absence of procedures for ecodesign in innovation processes and reported that their work is much about supporting and chaperoning companies which are eager to act and that their approach should not give the impression to "dictate" managers (catalyst's perspective). Interviewee D2 reported that she recurrently seeks to bring-in the focus on sustainability aspects in her presentations to senior managers (prophet's perspective), in a context where no specific direction or target come from a top-down perspective for product development.

Measures pertaining to the architect's perspective were considered or expected in several instances to facilitate other perspectives, especially the advocate's perspective. For example, formally incorporating sustainability in the organizational system was expected to provide the official scene for prioritizing time and resources on searching environment-friendly solutions at Company $G$ (Interviewee G2). Having corporate environmental targets was indicated to raise sustainability up in agendas throughout the organization at Company B. Interviewee E2 indicated that the establishment of a sustainability strategy had been a facilitator to bargain sustainability implementation with managers. Adding an ecodesign procedure to the product development process at Company A seems to have made it "normal" for project teams to look at environmental criteria throughout the project which may be interpreted as the influence of an architect's measure on the prophet's perspective.

We noted some instances where from a prophet's perspective, interviewees indicated methods which "work best" at their companies and how the latter were actually leveraged in measures from the architect's or advocate's perspective. Numbers and graphs are the normal way to display information at Company A, and in that sense integrating LCA in the product development process fits well with the scientific culture of the company as indicated by Interviewee A1. At Company D, concrete experiments are in the DNA of the organization, hence demonstrating the urgency for the company to integrate circular economy principles through a pilot study was found relevant, as reported by Interviewee D1.

We found a set of instances where the advocate's, catalyst's and prophet's perspectives seemed to act as facilitator for, or to complement the architect's perspective. From the catalyst's perspective, we noted for example the use of participatory approaches to design how to add ecodesign procedures to the current product development process together with product development teams (Company B; Company C). We also noted the influence of employees' own aspirations for ecodesign on the actual efforts deployed in developing solutions in projects, even if environmental assessments are formally part of the process, and thus the importance to intensively support those who are eager (Company A). From the advocate's perspective, we observed for instance a need to secure resources for more prospective projects to complement what can be done in common product development projects (Company A), and the idea that setting up new performance indicators is not enough to have people prioritize them (Company E). We also noted how taking an advocate's approach and putting efforts on those product development projects with a promising business case allows getting the marketing department onboard, and thus complement the architect's measure according to which an LCA must be conducted for each product development project (Company B). Finally, the prophet's perspective was associated for example with fighting misconceptions about who has the ability to influence product environmental performance in product development projects, and thus an important lever to encourage project teams to actually design environment-friendly solutions and to actually build on LCAs conducted for each project as a decision-support tool, rather than a mere documentation exercise (Company A).

\section{Discussion}

\subsection{Presence of the Four Lenses of Organizations}

The architect's perspective was evidently present in the results and directly corroborates the common recommendations from academia on integrating ecodesign aspects in the company's structure and processes $[11,12,19,21,64,65]$. We further noted the idea that strategies and goals need to be translated or broken down in lower levels of the organization, for specific business areas or on a project 
basis, which aligns with findings from earlier work [17]. The presence of the architect's perspective was further found in relation to challenges experienced by companies working with sustainability, about the difficulty to set a direction, doubts of where to set priorities and what KPIs to measure; calling for an architect's perspective to establish rational priorities, indicators and goals $[12,28,62]$. The importance of having capabilities specified in the company's organigram was highlighted at Company D which echoes with the findings of Boucher et al. [39]. On the other hand, we found that the discussion around having environmental targets for products varied depending on the context of the company, and more particularly on the nature of its products and drivers to develop environment-friendly products. In the present study, we could observe that in the case of ameliorative products [88], i.e., which inherently address sustainability-related needs (e.g., products developed to save energy or products developed to improve the life of seriously ill people), the development of a strategy related to products or performance targets which would include a broader range of sustainability issues was not a priority. Taking into account companies' strategic drivers to design relevant ecodesign integration approaches was also highlighted in earlier academic work [11]. Such insights from the present study are interesting to put in the perspective of literature insights which identified clear environmental goals, both at organizational and product development project level, or establishing environmental policies and targets for products as key success factors for ecodesign integration and green product innovation in companies, respectively $[64,89]$.

The results regarding the catalyst's perspective align with earlier studies recommending participatory approaches [21,29]. The idea indicated at one case company consisting of framing problems in terms engineers are familiar with, e.g., as an engineering problem, could be considered as a form of nudging, i.e., leading employees towards certain choices without inducing guilt or being prescriptive [18]. Also matching earlier findings, the need for increasing comfort of teams with the topic was evoked in several instances [28]. The advocate's perspective was clearly present in interviewees' elaborations about ecodesign integration, which contrast findings from studies on general managers' approaches $[56,57]$. The prominence of challenges for ecodesign integration related to resource allocation, tradeoffs management and low priority on senior management agenda, may explain a high focus on an advocate's perspective from ecodesign proponents. The importance of building the "business case" for sustainability and presenting product environmental information in terms which make great sense for the business was also acknowledged in existing literature $[13,71,90]$. Interestingly, we found a somewhat lower presence of the prophet's perspective in measures indicated at the case companies. Earlier studies in the general management literature found that managers did not make extensive use of the symbolic lens $[48,56,57]$. The confusion around who has the responsibility and ability to influence the product environmental performance mentioned at one case company was previously highlighted by Johansson and Magnusson; in their study, it was identified as driven by the existence of a separate work stream dealing with environmental aspects in the investigated project [65].

\subsection{Relations between the Lenses of Organizations}

Our findings regarding the relations between perspectives of organizations interestingly echo with different aspects outlined in existing literature on ecodesign integration. In earlier academic work, scholars have highlighted the facilitating role of architect's measures on the other perspectives of organizations. Measures from an architect's perspective, e.g., integration in process and targets, have been found to result in a change in mentalities and higher motivation among employees [91]; more familiarity with, cooperation around, understanding and acceptance of ecodesign practices [12]; more cross-functional cooperation, networking and understanding of each other's roles [65]; higher priority for ecodesign in agendas both of product development teams and senior management $[65,92]$. In the present study, we found similar examples of a facilitating role played by architect's measures, yet no example of facilitation over the catalyst's perspective were mentioned. The facilitation was mostly emphasized by interviewees in the context of prioritizing ecodesign in agendas and daily work, hence on the advocate's perspective. 
The observed facilitating or complementary roles of the advocate's, catalyst's, and prophet's perspectives on architect's measures match conclusions from other studies in which informal aspects of organizations were emphasized. Building on interviews conducted at four large companies, Kivimaa argued that the sole use of codified practices, e.g., LCA, does not guarantee a common understanding within the organization and emphasized the role of people-based approaches, i.e., cross-functional integration and training in environmental issues, for environmental integration in innovation [27]. Based on field work in two large companies, Skelton et al. concluded that the use of boundary objects for ecodesign integration, e.g., environmental improvement targets, which can be associated with an architect's perspective, "only establish specific instances where the environmental specialists can communicate around ecodesign and increase the engineers' level of awareness" [29] (p. 54). They further found that the use of boundary objects was not sufficient to integrate brokers, i.e., people working in functions supporting ecodesign integration, inside the product development community; neither to change the behavior of the product development community [29]. Arguing that nowadays managerial approaches tend to place less emphasis on command and control mechanisms (architect's perspective) to the benefit of increasing team autonomy, Brones et al. highlighted the need for "soft" mechanisms to lead the organization towards green innovation practices, e.g., fostering employees' engagement [18]. The insufficiency of architects' measures to guarantee successful ecodesign integration was also highlighted by Dekoninck et al. who indicated that solutions to address ecodesign integration challenges were often about introducing new tools, to the detriment of understanding why employees may lack motivation or be resistant [13].

Earlier academic studies exploring and comparing companies' trajectories of sustainability integration found that they did not all use architects' versus informal measures to the same extent, but rather adopted approaches which would best suit their organizational culture $[76,93,94]$. In the current study, all case companies seemed to agree to the importance of measures from the architect's perspective and none mentioned an integration effort solely based on informal aspects. Yet, the idea of matching the company's culture appeared in the mentioned prophet's measure consisting of using "what works best in the organization" to support ecodesign integration. The relative importance of measures from different lenses of organizations in different company contexts could be relevant to investigate in a larger sample of companies.

\subsection{Influence of Interviewee Position and Company Context}

Interviewees involved in the present study had either a sustainability-related position in their company or worked in a core business function and had some interest in pushing the ecodesign agenda in their organization. All interviewees indicated measures related to the architect's perspective. However, the formal integration of ecodesign aspects in the company's activities was one of the focuses of the interviews, and hence could have biased to some extent the perceptions of interviewees towards the relevance and need for measures from the architect's perspective. The advocate's perspective was also present in most interviews. Considering the sample size, it is difficult to draw any firm conclusion regarding the influence of the interviewee's position. We found that the interviewees in sustainability functions mentioned measures pertaining to at least three perspectives and more than half of them to all the four perspectives of organizations. On the other hand, more than half of the interviewees in core activity functions indicated measures from three different perspectives, and the others from one or two. Seniority in the organization or experience with working with sustainability-related topics did not seem to influence the number of lenses expressed by interviewees, as we did not observe clear differences in lens coverage between experienced and less-experienced interviewees. Yet, the influence of the above-mentioned parameters should be further studied in future research based on direct inquiries of the four lenses, as in the present exploratory study only weak indications could be retrieved.

The present work constitutes a Nordic case study as all case companies were in Nordic countries. This regional focus may have influenced the extent to which the different lenses of organizations could be observed. For instance, one interviewee from Company E referred to a Nordic style of working 
when describing that she seeks to empower employees by making them "understand why they need to do something and what is expected from them", before letting them "find out what is needed to be done in detail". This echoes with observations reported in earlier work touching upon the relative freedom of employees in Nordic organizations on how to achieve given targets [95], and could be in favor of the catalyst's perspective. At Company A, it was emphasized that there is a consensus culture, which leads to discussing solutions rather intensively in development projects. At Company D, one interviewee indicated that the organizational structure is rather flat and that they "can go directly from [their] department to another department". Both these factors could create a favorable ground for approaches stemming from the catalyst's, advocate's, and prophet's perspectives. On the other hand, the companies included in our sample are large market players, externally recognized for their sustainability efforts (e.g., listed in DJSI). From this perspective, the coverage of lenses found in the present study may not be representative of smaller companies or companies with less mature sustainability approaches.

\subsection{Limitations of the Study}

Only a limited number of interviews could be conducted at the case companies, especially at Company $\mathrm{B}$ where only one could be conducted. It is thus important to acknowledge that the phenomenon under study and presented in this article remains closely related to interviewees' perceptions, which is yet common for this type of research. Deriving concrete recommendations for the case companies would require a larger scope of investigation, but for the present study, the views of interviewees constitute relevant indications about the different lenses of organizations. This work was exploratory per definition and based on a case study design; hence this naturally limits the statistical generalizability of our findings which should be tested in future work on larger samples of companies [82]. Although the interview data allowed for tracking the presence of the different lenses of organizations in interviewees' descriptions of ecodesign integration at their company, the empirical part of the study remains based on a secondary data source, and thus may not give a fully representative picture of the presence of the lenses. More targeted questions could have yielded different results in terms of lenses' relative presence. Yet, the absence of questions targeted for each lens may, on the other hand, have been an advantage as it avoided social desirability or prestige biases, which can typically occur in direct questioning settings and imply that respondents tend to answer based on what is most socially accepted rather than based on the truth or on what is perceived as expected by the interviewer, respectively [96]. It also prevented any potential connotations associated with the different perspectives of organizations, e.g., "architect" (positively connoted) versus "prophet" (negatively connoted). However, future research designs based on direct inquiries of the four lenses, e.g., using a questionnaire adapted from the leadership orientation instrument [48], are needed in order to further our understanding of the role of the four lenses in ecodesign integration in companies.

\section{Conclusions}

Departing from the need to investigate and support ecodesign integration at companies, while accounting for formal and informal aspects of organizational functioning, we drew on the four-lens view of organizations and explored the presence and relations between the different lenses in ecodesign integration. The study built on interviews of ecodesign proponents at a set of Danish and Norwegian case companies in diverse manufacturing sectors. First, the analysis revealed the presence of the architect's, catalyst's, advocate's, and prophet's perspectives in the measures mentioned to support ecodesign integration at the case companies. Second, the results provided indications about relations between the different lenses, among which two seemed to stand out: (i) measures from the architect's perspective seemed considered or expected to provide an official scene for prioritizing ecodesign in the organization, hence facilitating the advocate's perspective; and (ii) measures stemming from the catalyst's, advocate's and prophet's perspectives were observed to act as facilitator or complement of measures from an architect's perspective to push the ecodesign agenda at companies. Overall, this 
exploratory study suggests that the four-lens view of organizations is pertinent to investigate and support ecodesign integration in organizational contexts.

From a theoretical point of view, our study contributes to the research field of ecodesign integration in companies with a new theoretical perspective stemming from the general management literature. Based on exploratory case studies, this work has investigated the potential of the four-lens view of organizations to support ecodesign integration in companies and brought initial evidence on the need for embracing the different lenses. This is a starting point for future work. Direct investigations of the lenses' presence in ecodesign integration efforts of larger samples of companies in different contexts should be the object of future studies to test the generalizability of our findings and expand our understanding of a multi-lens approach to support ecodesign integration in companies. Notably, interconnections between lenses need further investigation. Furthermore, it could be particularly relevant to (i) identify lenses which are critical, i.e., weakly established although recognized as highly necessary, in the opinion of ecodesign proponents in industry; (ii) study possible correlations between the lenses' coverage in ecodesign integration efforts and ecodesign performance indicators; (iii) study the relative importance of lenses in different organizational contexts, e.g., depending on the company persona [97]. From a practical perspective, our study provides ecodesign proponents in companies with a conceptual framework from the general management literature and its translation into the ecodesign integration context, with concrete measures to support ecodesign integration from the different perspectives of organizations and insights of the relative role of the different lenses.

Considering the challenges associated with ecodesign integration in companies together with the recurrently acknowledged need to account for the specific context of companies rather than providing one-size-fits-all models $[18,59,76,98]$, the development of reflective tools whose primary objective would be to steer reflections from company practitioners about their current situation and challenges, seems a particularly interesting area to explore [99]. From this perspective, the potential formalization of the four-lens view of organizations into a reflective tool for ecodesign proponents is identified as an avenue for future research.

Author Contributions: Conceptualization, R.S.; Data curation, R.S. and F.A.; Formal analysis, R.S.; Investigation, R.S. and F.A.; Methodology, R.S., F.A., C.B. and N.B.; Supervision, C.B. and N.B.; Validation, F.A., C.B. and N.B.; Writing-Original Draft, R.S.; Writing-Review and Editing, F.A., C.B. and N.B.

Funding: This research was internally funded by DTU and NTNU as part of a cotutelle agreement.

Conflicts of Interest: The authors declare no conflict of interest.

\section{Appendix A. Themes Addressed during the Interviews}

- Current integration of ecodesign in the company: Processes? Tools? Strategies? Goals? Challenges?

- Interactions with other departments on ecodesign: form, challenges, and enablers?

- Interactions with other businesses on ecodesign (suppliers, distributors, customers, reprocessors, competitors, companies in other business areas): form, challenges, and enablers?

\section{Appendix B. Details about the Coding Results}

Table A1. Results from the revision of the coding results.

\begin{tabular}{cccc}
\hline & $\begin{array}{c}\text { Number of Reviewed } \\
\text { Coded Units }\end{array}$ & $\begin{array}{c}\text { Percentage of } \\
\text { Discussed Coded Units }\end{array}$ & $\begin{array}{c}\text { Percentage of Changed } \\
\text { Coded Units }\end{array}$ \\
\hline Co-author 1 & 52 & $12 \%$ & $4 \%$ \\
Co-author 2 & 49 & $18 \%$ & $6 \%$ \\
Co-author 3 & 49 & $39 \%$ & $18 \%$ \\
\hline
\end{tabular}


Table A2. Lens distribution of coded units identified for each case company. Please note that the total number of coded units varies from one case company to the other.

\begin{tabular}{cccccc}
\hline & $\begin{array}{c}\text { Architect } \\
\text { (Structural) }\end{array}$ & $\begin{array}{c}\text { Catalyst } \\
\text { (Human) }\end{array}$ & $\begin{array}{c}\text { Advocate } \\
\text { (Political) }\end{array}$ & $\begin{array}{c}\text { Prophet } \\
\text { (Symbolic) }\end{array}$ & $\begin{array}{c}\text { Total Number of Coded } \\
\text { Units (=100\%) }\end{array}$ \\
\hline Company A & $36 \%$ & $19 \%$ & $33 \%$ & $11 \%$ & 36 \\
Company B & $53 \%$ & $16 \%$ & $32 \%$ & $0 \%$ & 19 \\
Company C & $37 \%$ & $26 \%$ & $33 \%$ & $4 \%$ & 27 \\
Company D & $54 \%$ & $7 \%$ & $18 \%$ & $21 \%$ & 28 \\
Company E & $59 \%$ & $21 \%$ & $21 \%$ & $0 \%$ & 34 \\
Company F & $67 \%$ & $0 \%$ & $22 \%$ & $11 \%$ & 38 \\
Company G & $71 \%$ & $0 \%$ & $13 \%$ & $16 \%$ & 191 \\
\hline
\end{tabular}

Table A3. List of second-cycle coding categories in each lens of organizations and examples of associated first-cycle coding phrases. LCA = Life Cycle Assessment; ERP = Enterprise Resource Planning; KPI = Key Performance Indicator.

\begin{tabular}{|c|c|}
\hline Second-Cycle Coding Category & Examples of First-Cycle Coding Phrase \\
\hline \multicolumn{2}{|l|}{ Architect's Perspective } \\
\hline $\begin{array}{l}\text { Integrate ecodesign procedure in product } \\
\text { development process }\end{array}$ & $\begin{array}{l}\text { "There is a mandatory procedure in product } \\
\text { development projects for dealing with environmental } \\
\text { aspects"; "The project manager has the responsibility to } \\
\text { show environmental documentation at gates" }\end{array}$ \\
\hline Acquire/develop tools for decision-making & $\begin{array}{l}\text { "Development of in-house LCA capabilities"; "LCA used } \\
\text { to compare products with competitors' or } \\
\text { earlier generations" }\end{array}$ \\
\hline Design strategy related to products & $\begin{array}{l}\text { "Need for having sustainability as part of the business } \\
\text { strategy, so that teams can take decisions based on } \\
\text { environmental criteria" }\end{array}$ \\
\hline Set directions/goals/targets & $\begin{array}{l}\text { "The company has targets for products at high level"; } \\
\text { "Set up a direction to be able to ask some funding to try } \\
\text { out some alternative options in products"; "Set up a } \\
\text { direction to be able to go all in when scouting for } \\
\text { alternative options and have more margin to discuss with } \\
\text { suppliers directly" }\end{array}$ \\
\hline Develop guidelines related to product development & $\begin{array}{l}\text { "Create a shared repository about eco-labels"; "Produce } \\
\text { central guidelines for packaging material" }\end{array}$ \\
\hline $\begin{array}{l}\text { Formally define "sustainability" } \\
\text { (e.g., standard, criteria) }\end{array}$ & $\begin{array}{l}\text { "Define what "sustainability" means for the department"; } \\
\text { "Define what a sustainable product is formally" }\end{array}$ \\
\hline $\begin{array}{l}\text { Translate strategy into action plan for specific } \\
\text { business units/functions }\end{array}$ & $\begin{array}{l}\text { "Define what the sustainability strategy implies at the } \\
\text { function level"; "Develop a sustainability strategy and } \\
\text { tailored translation tools" }\end{array}$ \\
\hline $\begin{array}{l}\text { Translate corporate targets into targets for individual } \\
\text { innovation projects }\end{array}$ & $\begin{array}{l}\text { "Breaking down high level targets to innovation } \\
\text { project targets" }\end{array}$ \\
\hline Create sustainability roles & $\begin{array}{l}\text { "Slowly building the organizational structure around } \\
\text { sustainability in the organization" }\end{array}$ \\
\hline Set up new KPIs & "Set up new KPIs for the purchasing department" \\
\hline Use a process with more experimental approach & $\begin{array}{l}\text { "The set up for the sustainability dedicated project } \\
\text { outside the stage gate model of the company is great } \\
\text { because decisions can be taken more quickly" }\end{array}$ \\
\hline
\end{tabular}


Table A3. Cont.

\begin{tabular}{|c|c|}
\hline Second-Cycle Coding Category & Examples of First-Cycle Coding Phrase \\
\hline \multicolumn{2}{|l|}{ Catalyst's Perspective } \\
\hline Support/chaperon initiatives & $\begin{array}{l}\text { "Make sure that the parties continue the project (since it } \\
\text { is side track for them)"; "Support individual managers in } \\
\text { their attempt to integrate sustainability issues in } \\
\text { their work" }\end{array}$ \\
\hline $\begin{array}{l}\text { Increase comfort of people to work with the topic } \\
\text { of ecodesign }\end{array}$ & $\begin{array}{l}\text { "Make material digestible, focus on having teams } \\
\text { comfortable discussing sustainability"; "Clarify tasks and } \\
\text { implied workload for people to feel comfortable about it" }\end{array}$ \\
\hline Build individual awareness of impact of decisions & $\begin{array}{l}\text { "Have people understand how their decisions impact the } \\
\text { product environmental performance" }\end{array}$ \\
\hline Leverage people's aspirations & $\begin{array}{l}\text { "Involve people who burn for the topic"; "Specifically } \\
\text { support people that are eager to bring change because it } \\
\text { all comes down to people's passion" }\end{array}$ \\
\hline $\begin{array}{l}\text { Participative approach to adapt the product } \\
\text { development process }\end{array}$ & $\begin{array}{l}\text { "Co-design with product development teams how the } \\
\text { LCA tool will be used in the process" }\end{array}$ \\
\hline Frame ecodesign challenges in familiar terms & $\begin{array}{l}\text { "Translate ideas into concrete technical challenges to be } \\
\text { solved by engineers who are good at it" }\end{array}$ \\
\hline Give autonomy & $\begin{array}{l}\text { "Tell people what their end goal is and let them find the } \\
\text { way there" }\end{array}$ \\
\hline Trigger people/"plant seeds" & "Trigger people by evoking the ecodesign topic" \\
\hline \multicolumn{2}{|l|}{ Advocate's Perspective } \\
\hline Align with business/stakeholders' agenda & $\begin{array}{l}\text { "Identify critical resources in ERP system, match with } \\
\text { business case to convince sourcing manager" }\end{array}$ \\
\hline Negotiate prioritization of ecodesign in agendas & $\begin{array}{l}\text { "Need for more priority on sustainability aspects when } \\
\text { prioritizing projects"; "Bargain with management for } \\
\text { sustainability KPIs to actually be prioritized } \\
\text { in purchasing" }\end{array}$ \\
\hline Emphasize criticality/emergency for business & $\begin{array}{l}\text { "Make top management understand the underlying risks } \\
\text { of sustainability aspects" }\end{array}$ \\
\hline Target efforts/"pick battles" & $\begin{array}{l}\text { "Target areas of the organization where change is easier } \\
\text { to operate, e.g., in product maintenance rather than } \\
\text { product development"; "Focus on high potential for } \\
\text { sustainability story, sustainability needs to be shown as a } \\
\text { win to marketing" }\end{array}$ \\
\hline $\begin{array}{l}\text { Ally with/get support from relevant people in } \\
\text { the company }\end{array}$ & $\begin{array}{l}\text { "Get people that are listened to, to speak up for } \\
\text { environmentally preferable options" }\end{array}$ \\
\hline Have answers to all technical questions & $\begin{array}{l}\text { "Seek good arguments from expert judgements"; } \\
\text { "Convince people that something is technically possible" }\end{array}$ \\
\hline Leverage network in the company & $\begin{array}{l}\text { "Leverage personal relationship to have people work } \\
\text { outside the normal working flow"; "Create a network of } \\
\text { sustainability responsible people in the organizations } \\
\text { where they share knowledge, best practices and } \\
\text { can collaborate" }\end{array}$ \\
\hline $\begin{array}{l}\text { Secure present resource allocation for long } \\
\text { term/more prospective objectives }\end{array}$ & $\begin{array}{l}\text { "Need prioritizing resources for projects specifically } \\
\text { targeted at finding alternative to conventional plastics } \\
\text { because no obvious green solutions"; "Need to invest in } \\
\text { knowledge and competence for sustainability even if it is } \\
\text { long term" }\end{array}$ \\
\hline Leverage existing umbrella projects & $\begin{array}{l}\text { "Leverage existing project as an umbrella for activities so } \\
\text { that resources and momentum are already there" }\end{array}$ \\
\hline
\end{tabular}


Table A3. Cont.

\begin{tabular}{|c|c|}
\hline Second-Cycle Coding Category & Examples of First-Cycle Coding Phrase \\
\hline \multicolumn{2}{|l|}{ Prophet's Perspective } \\
\hline Manage beliefs/"truths" in the company & $\begin{array}{l}\text { "Change mindset that sustainability is a cost"; } \\
\text { "Challenge common beliefs in the organization by } \\
\text { delivering data" }\end{array}$ \\
\hline Change perceived vision/mission of the company & $\begin{array}{l}\text { "Change what people believe they are working for"; } \\
\text { "Spread around that the company has ambition } \\
\text { for sustainability" }\end{array}$ \\
\hline Leverage "typical ways of doing" & $\begin{array}{l}\text { "Use experiments which are in the DNA of the company } \\
\text { to show relevance of ecodesign aspects" }\end{array}$ \\
\hline Preach in the company & $\begin{array}{l}\text { "Use a 10-min of fame to brief teams about } \\
\text { environmental challenges at beginning of each project"; } \\
\text { "Spread around the concept of circular economy (make } \\
\text { sure everyone knows what it is about)" }\end{array}$ \\
\hline Provide inspiration from outside & $\begin{array}{l}\text { "Gain insights from young generations' thoughts on } \\
\text { sustainability"; "Bring external inputs to } \\
\text { change mindsets" }\end{array}$ \\
\hline
\end{tabular}

\section{References}

1. International Organization for Standardization. ISO 14001 Environmental Management Systems-Revision 2015; International Organization for Standardization: Geneva, Switzerland, 2015.

2. Lewandowska, A.; Matuszak-flejszman, A. Eco-design as a normative element of Environmental Management Systems-The context of the revised ISO 14001: 2015. Int. J. Life Cycle Assess. 2015, 19, 1794-1798. [CrossRef]

3. Pigosso, D.C.A.; McAloone, T.C.; Rozenfeld, H. Characterization of the State-of-the-art and Identification of Main Trends for Ecodesign Tools and Methods: Classifying Three Decades of Research and Implementation. J. Indian Inst. Sci. 2015, 95, 405-427.

4. European Commission Facts and Figures-Ecolabel-EUROPA. Available online: http://ec.europa.eu/ environment/ecolabel/ facts-and-figures.html (accessed on 29 June 2018).

5. Fargnoli, M.; Costantino, F.; Tronci, M.; Bisillo, S. Ecological profile of industrial products over the environmental compliance. Int. J. Sustain. Eng. 2013, 6, 117-130. [CrossRef]

6. United Nations General Assembly. Resolution Adopted by the General Assembly on 25 September 2015: Transforming Our World: The 2030 Agenda for Sustainable Development A/RES/70/1; United Nations General Assembly: New York, NY, USA, 2015.

7. Ceschin, F.; Gaziulusoy, I. Evolution of design for sustainability: From product design to design for system innovations and transitions. Des. Stud. 2016, 47, 118-163. [CrossRef]

8. McAloone, T.C.; Pigosso, D.C.A. From Ecodesign to Sustainable Product/Service-Systems: A Journey Through Research Contributions over Recent Decades Sustainable innovation. In Sustainable Manufacturing. Sustainable Production, Life Cycle Engineering and Management; Stark, R., Seliger, G., Bonvoisin, J., Eds.; Springer: Cham, Switzerland, 2017; pp. 99-111, ISBN 9783319485140.

9. Den Hollander, M.C.; Bakker, C.A.; Hultink, E.J. Product Design in a Circular Economy Development of a Typology of Key Concepts and Terms. J. Ind. Ecol. 2017, 21, 517-525. [CrossRef]

10. Short, T.; Lee-Mortimer, A.; Luttropp, C.; Johansson, G. Manufacturing, sustainability, ecodesign and risk: Lessons learned from a study of Swedish and English companies. J. Clean. Prod. 2012, 37, 342-352. [CrossRef]

11. Pigosso, D.C.A.; Rozenfeld, H.; McAloone, T.C. Ecodesign maturity model: A management framework to support ecodesign implementation into manufacturing companies. J. Clean. Prod. 2013, 59, 160-173. [CrossRef]

12. Poulikidou, S.; Björklund, A.; Tyskeng, S. Empirical study on integration of environmental aspects into product development: Processes, requirements and the use of tools in vehicle manufacturing companies in Sweden. J. Clean. Prod. 2014, 81, 34-45. [CrossRef] 
13. Dekoninck, E.A.; Domingo, L.; O’hare, J.A.; Pigosso, D.C.A.; Reyes, T.; Troussier, N. Defining the challenges for ecodesign implementation in companies: Development and consolidation of a framework. J. Clean. Prod. 2016, 135, 410-425. [CrossRef]

14. Rousseaux, P.; Gremy-Gros, C.; Bonnin, M.; Henriel-Ricordel, C.; Bernard, P.; Floury, L.; Staigre, G.; Vincent, P. "Eco-tool-seeker" A new and unique business guide for choosing ecodesign tools. J. Clean. Prod. 2017, 151, 546-577. [CrossRef]

15. Baumann, H.; Boons, F.; Bragd, A. Mapping the green product development field: Engineering, policy and business perspectives. J. Clean. Prod. 2002, 10, 409-425. [CrossRef]

16. Dewulf, W.; Duflou, J.R. Integrating eco-design into business environments. A multi-level approach. In Product Engineering. Eco-Design, Technologies and Green Energy; Talaba, D., Roche, T., Eds.; Springer Science: Dordrecht, The Netherlands, 2005; pp. 55-76, ISBN 1-4020-2932-2.

17. Boks, C. The soft side of ecodesign. J. Clean. Prod. 2006, 14, 1346-1356. [CrossRef]

18. Brones, F.A.; de Carvalho, M.M.; De Senzi Zancul, E. Reviews, action and learning on change management for ecodesign transition. J. Clean. Prod. 2017, 142, 8-22. [CrossRef]

19. Brones, F.; De Carvalho, M.M.; De Senzi Zancul, E. Ecodesign in project management: A missing link for the integration of sustainability in product development? J. Clean. Prod. 2014, 80, 106-118. [CrossRef]

20. Ali, F.; Boks, C.; Bey, N. Design for sustainability and project management literature-A review of literature. Procedia CIRP 2016, 48, 28-33. [CrossRef]

21. Bonou, A.; Skelton, K.; Olsen, S.I. Ecodesign framework for developing wind turbines. J. Clean. Prod. 2016, 126, 643-653. [CrossRef]

22. Hallstedt, S.; Pigosso, D. Sustainability integration in a technology readiness assessment framework. In Proceedings of the 21st International Conference on Engineering Design (ICED 17) Vol 5: Design for $X$, Design to X, Vancouver, BC, Canada, 21-25 August 2017; pp. 229-238.

23. Ammenberg, J.; Sundin, E. Products in environmental management systems: Drivers, barriers and experiences. J. Clean. Prod. 2005, 13, 405-415. [CrossRef]

24. Rodrigues, V.P.; Pigosso, D.C.A.; Andersen, J.W.; McAloone, T.C. Evaluating the Potential Business Benefits of Ecodesign Implementation: A Logic Model Approach. Sustainability 2018, 10, 2011. [CrossRef]

25. Landeta Manzano, B.; Arana-Landin, G.; Ruiz de Arbulo, P.; Diaz de Basurto, P. Sustainability Through Eco-Design: Shedding Light on the Adoption of the ISO 14006 Standard. In Sustainable Operations Management. Measuring Operations Performance; Springer: Cham, Switzerland, 2015; pp. 163-181, ISBN 9783319140025.

26. Arana-landin, G.; Heras-saizarbitoria, I. Paving the way for the ISO 14006 ecodesign standard: An exploratory study in Spanish companies. J. Clean. Prod. 2011, 19, 1007-1015. [CrossRef]

27. Kivimaa, P. Integrating environment for innovation: Experiences from product development in paper and packaging. Organ. Environ. 2008, 21, 56-75. [CrossRef]

28. Verhulst, E.; Boks, C. The role of human factors in the adoption of sustainable design criteria in business: Evidence from Belgian and Dutch case studies. Int. J. Innov. Sustain. Dev. 2012, 6, 146. [CrossRef]

29. Skelton, K.; Huulgaard, R.D.; Schmidt, K. Understanding ecodesign through a communities of practice perspective. Int. J. Environ. Technol. Manag. 2016, 19, 40. [CrossRef]

30. Nadler, D. Managing Organizational Change: An integrative perspective. J. Appl. Behav. Sci. 1981, 17, 191-211. [CrossRef]

31. Bolman, L.G.; Deal, T.E. Reframing Organizations: Artistry, Choice and Leadership, 4th ed.; John Wiley \& Sons, Ed.; Jossey-Bass: San Francisco, CA, USA, 2008; ISBN 9780787987985.

32. Walker, P. What's it like from the inside? The Challenges of Being an Organisational Change Agent for Sustainability. Greener Manag. Int. 2007, 57, 9-25. [CrossRef]

33. Bey, N.; Hauschild, M.Z.; McAloone, T.C. Drivers and barriers for implementation of environmental strategies in manufacturing companies. CIRP Ann.-Manuf. Technol. 2013, 62, 43-46. [CrossRef]

34. Cantor, D.E.; Morrow, P.C.; McElroy, J.C.; Montabon, F. The role of individual and organizational factors in promoting firm environmental practices. Int. J. Phys. Distrib. Logist. Manag. 2013, 43, 407-427. [CrossRef]

35. Opoku, A.; Fortune, C. The implementation of sustainable practices through leadership in construction organizations. In Proceedings of the 27th Annual ARCOM Conference, Bristol, UK, 5-7 September 2011; pp. 1145-1154.

36. Taylor, A.; Cocklin, C.; Brown, R. Fostering environmental champions: A process to build their capacity to drive change. J. Environ. Manag. 2012, 98, 84-97. [CrossRef] [PubMed] 
37. Dunphy, D.; Griffiths, A.; Benn, S. Organizational Change for Corporate Sustainability. A Guide for Leaders and Change Agents of the Future; Routled: New York, NY, USA, 2007; ISBN 978-0415393300.

38. Holton, I.; Glass, J.; Price, A.D.F. Managing for sustainability: Findings from four company case studies in the UK precast concrete industry. J. Clean. Prod. 2010, 18, 152-160. [CrossRef]

39. Boucher, J.; Jenny, C.; Plummer, Z.; Schneider, G. How to Avoid Pigeonholing the Environmental Manager? Sustainability 2018, 10, 2538. [CrossRef]

40. Taylor, F.W. The Principles of Scientific Management; Harper: New York, NY, USA, 1911.

41. Weber, M. The Theory of Social and Economic Organization; Free Press: New York, 1947; ISBN 9781614272571.

42. Mintzberg, H. The Structuring of Organizations; Prentice Hall: Upper Saddle River, NJ, USA, 1979; ISBN 9780138552701.

43. McGregor, D. The Human Side of Enterprise; McGraw-Hill: New York, NY, USA, 1960; ISBN 9780070450929.

44. Argyris, C. Integrating the Individual and the Organization, 1st ed.; Wiley: New York, NY, USA, 1964; ISBN 9781351512176.

45. Kotter, J.P. Power and Influence: Beyond Formal Authority; Free Press: New York, NY, USA, 1985; ISBN 9781439146798.

46. Pfeffer, J. Power in Organizations; Pitman: Boston, MA, USA, 1881; ISBN 9780273016380.

47. Schein, E.H. Organizational Culture and Leadership; Jossey-Bass: San Francisco, CA, USA, 1992; ISBN 1-55542-487-2.

48. Bolman, L.; Deal, T. Leadership and Management effectiveness: A multi-frame, multi-sector analysis. Hum. Resour. Manag. 1991, 30, 509-534. [CrossRef]

49. Hulpiau, V.; Waeytens, K. Improving quality of education: What makes it actually work? A case study. In Proceedings of the International Research Conference Higher Education Close Up 2, Lancashire, UK, 16-18 July 2001; pp. 1-16.

50. Bajis, D.; Chaar, B.; Basheti, I.A.; Moles, R. Identifying perceptions of academic reform in pharmacy using a four-frame organizational change model. Res. Soc. Adm. Pharm. 2017. [CrossRef] [PubMed]

51. Bernardes, A.; Cummings, G.G.; Gabriel, C.S.; Martinez Évora, Y.D.; Gomes Maziero, V.; Coleman-Miller, G. Implementation of a participatory management model: Analysis from a political perspective. J. Nurs. Manag. 2015, 23, 888-897. [CrossRef] [PubMed]

52. Janz, K.; Hall, S.; Honken, R.; Hall, S. Personality Inventories and Cognitive Frames: Understanding the Balance in Managing and Leading IT Organizations. In Proceedings of the 41st Annual ACM SIGUCCS User Services Conference, Chicago, IL, USA, 3-8 November 2013; pp. 143-150.

53. Sjøback, B.; Knutstad, G. Reframing the Outsourcing Process. In Advances in Production Management Systems. The Path to Intelligent, Collaborative and Sustainable Manufacturing. IFIP WG 5.7 International Conference, APMS 2017, Hamburg, Germany, September 3-7, 2017, Proceedings, Part II; Lödding, H., Riedel, R., Thoben, K.D., von Cieminski, G., Kiritsis, D., Eds.; Springer: Cham, Switzerland, 2017; pp. 20-28, ISBN 978-3-319-66926-7.

54. Swan-sein, A.; Mellman, L.; Balmer, D.F.; Richards, B.F. Sustaining an Advisory Dean Program and Evaluation. Acad. Med. 2012, 87, 523-528. [CrossRef] [PubMed]

55. Fleming-may, R.A.; Douglass, K. Framing Librarianship in the Academy: An Analysis Using Bolman and Deal' s Model of Organizations. Coll. Res. Libr. 2014, 75, 389-415. [CrossRef]

56. Sasnett, B.; Ross, T. Leadership frames and perceptions of effectiveness among health information management program directors. Perspect. Health Inf. Manag. 2007, 4, 8. [PubMed]

57. McGowan, E.; Walsh, C.; Stokes, E. Physiotherapy managers' perceptions of their leadership effectiveness: A multi-frame analysis. Physiotherapy 2017, 103, 289-295. [CrossRef] [PubMed]

58. Thompson, M.D. Gender, Leadership Orientation, and Effectiveness: Testing the Theoretical Models of Bolman \& Deal and Quinn. Sex Roles 2000, 42, 969-992. [CrossRef]

59. Brones, F.; Monteiro De Carvalho, M. From 50 to 1: Integrating literature toward a systemic ecodesign model. J. Clean. Prod. 2015, 96, 44-47. [CrossRef]

60. Stewart, R.; Bey, N.; Boks, C. Exploration of the Barriers to Implementing Different Types of Sustainability Approaches. Procedia CIRP 2016, 48, 22-27. [CrossRef]

61. Handfield, R.B.; Calantone, R.J.; Melnyk, S. Integrating environmental concerns into the design process: The gap between theory and practice. IEEE Trans. Eng. Manag. 2001, 48, 189-208. [CrossRef]

62. Alblas, A.A.; Peters, K.; Wortman, H.J. Fuzzy sustainability incentives in new product development. Int. J. Oper. Prod. Manag. 2014, 34, 513-545. [CrossRef] 
63. Hallstedt, S.; Ny, H.; Robèrt, K.-H.; Broman, G. An approach to assessing sustainability integration in strategic decision systems for product development. J. Clean. Prod. 2010, 18, 703-712. [CrossRef]

64. Johansson, G. Success factors for integration of ecodesign in product development. Environ. Manag. Heal. 2002, 13, 98-107. [CrossRef]

65. Johansson, G.; Magnusson, T. Organising for environmental considerations in complex product development projects: Implications from introducing a "Green" sub-project. J. Clean. Prod. 2006, 14, 1368-1376. [CrossRef]

66. Ritzén, S.; Beskow, C. Actions for integrating environmental aspects into product development Sofia. J. Sustain. Prod. Des. 2001, 1, 91-102. [CrossRef]

67. Deutz, P.; McGuire, M.; Neighbour, G. Eco-design practice in the context of a structured design process: An interdisciplinary empirical study of UK manufacturers. J. Clean. Prod. 2013, 39, 117-128. [CrossRef]

68. Schulte, J.; Hallstedt, S. Challenges and preconditions to build capabilities for sustainable product design. In Proceedings of the 21st International Conference on Engineering Design (ICED 17) Vol 5: Design for X, Design to X, Vancouver, BC, Canada, 21-25 August 2017; pp. 1-10.

69. Verhulst, E. The Human Side of Sustainable Design Implementation from the Perspective of Change Management. Ph.D. Thesis, University of Antwerp, Antwerp, Belgium, 2011.

70. Aschehoug, S.H.; Boks, C.; Storen, S. Environmental information from stakeholders supporting product development. J. Clean. Prod. 2012, 31,1-13. [CrossRef]

71. Goedkoop, M.; Mieras, E.; Gaasbeek, A.; Contreras, S. How to Make the Life Cycle Assessment Team a Business Partner. In LCA Compendium-The Complete World of Life Cycle Assessment. Life Cycle Management; Sonnemann, G., Margni, M., Eds.; Springer: Dordrecht, The Netherlands, 2015; pp. 105-115, ISBN 978-94-017-7220-4.

72. Linnenluecke, M.K.; Russell, S.V.; Griffiths, A. Subcultures and Sustainability Practices: The Impact on Understanding Corporate Sustainability. Bus. Strateg. Environ. 2009, 18, 432-452. [CrossRef]

73. Eisenhardt, K.M. Building theories from case study research. Acad. Manag. J. 1989, 16, 620-627. [CrossRef]

74. Dangelico, R.M.; Pujari, D. Mainstreaming Green Product Innovation: Why and How Companies Integrate Environmental Sustainability. J. Bus. Ethics 2010, 95, 471-486. [CrossRef]

75. Hallstedt, S.I.; Thompson, A.W.; Lindahl, P. Key elements for implementing a strategic sustainability perspective in the product innovation process. J. Clean. Prod. 2013, 51, 277-288. [CrossRef]

76. Verhulst, E.; Boks, C. Bringing about sustainable change in product development: Theory versus practice. In Advances in Production Management Systems. Value Networks: Innovation, Technologies, and Management; Frick, J., Laugen, B.T., Eds.; Springer: Berlin/Heidelberg, Germany, 2012; pp. 448-457, ISBN 9783642122194.

77. Kara, S.; Honke, I.; Kaebernick, H. Integrated Framework for Implementing Sustainable Product. In Proceedings of the 4th International Symposium on Environmentally Conscious Design and Inverse Manufacturing, Tokyo, Japan, 12-14 December 2005; pp. 684-691.

78. Sousa, S.R.; Ometto, A.R. Application of Life Cycle Assessment in Service Industries: A Review. In Proceedings of the Life Cycle Management Conference, Berlin, Germany, 28-31 August 2011; pp. 1-9.

79. Stewart, R.; Fantke, P.; Owsianiak, M.; Bjørn, A.; Molin, C.; Hauschild, M.Z.; Laurent, A. Life cycle assessment in corporate sustainability reporting: Global, regional, sectoral and company-level trends. Bus. Strateg. Environ. 2018. [CrossRef]

80. Miles, M.; Huberman, A. Qualitative Data Analysis: A Sourcebook of New Methods; Sage: Newbury Park, CA, USA, 1994.

81. Thijssens, T.; Bollen, L.; Hassink, H. Managing sustainability reporting: Many ways to publish exemplary reports. J. Clean. Prod. 2016, 136, 86-101. [CrossRef]

82. Yin, R.K. Case Study Research. Design and Methods, 4th ed.; Sage: Newbury Park, CA, USA, 2009; Volume 5.

83. Hsieh, H.F.; Shannon, S.E. Three approaches to qualitative content analysis. Qual. Heal. Res. 2005, 15, 1277-1288. [CrossRef] [PubMed]

84. Graneheim, U.H.; Lundman, B. Qualitative content analysis in nursing research: Concepts, procedures and measures to achieve trustworthiness. Nurse Educ. Today 2004, 24, 105-112. [CrossRef] [PubMed]

85. Saldaña, J. The Coding Manual for Qualitative Researchers; SAGE Publications: London, UK, 2009; ISBN 9781847875488.

86. Riege, A.M. Validity and reliability tests in case study research: A literature review with "hands-on" applications for each research phase. Qual. Mark. Res. Int. J. 2003, 6, 75-86. [CrossRef] 
87. Transcribe Basic \& Verbatim Basic Transcriptions Rules. Available online: https:/ /www.transcribe.com/ transcription-jobs-online/style-guide/basic-verbatim/ (accessed on 29 June 2018).

88. Wever, R.; Boks, C.; Bakker, C.A. Sustainability within Product Portfolio Management. In Proceedings of the 13th International Conference Sustainable Innovation 08, Malmö, Sweden, 27-28 October 2008; pp. $219-227$.

89. Dangelico, R.M. Green Product Innovation: Where we are and Where we are Going. Bus. Strateg. Environ. 2015. [CrossRef]

90. Veshagh, A.; Marval, S.; Woolman, T. Making the Business Case for Eco-Design and Sustainable Manufacturing. In Proceedings of the 19th CIRP Conference on Life Cycle Engineering, University of California at Berkeley, Berkeley, CA, USA, 23-25 May 2012; Dornfeld, D., Linke, B., Eds.; Springer: Berlin, Germany, 2012; pp. 11-17.

91. Arnold, M.G.; Hockerts, K. The Greening Dutchman: Philips' Process of Green Flagging to Drive Sustainable Innovations. Bus. Strateg. Environ. 2011, 407, 394-407. [CrossRef]

92. Petala, E.; Wever, R.; Dutilh, C.; Brezet, H. The role of new product development briefs in implementing sustainability: A case study. J. Eng. Technol. Manag. 2010, 27, 172-182. [CrossRef]

93. Van Der Heijden, A.; Driessen, P.P.J.; Cramer, J.M. Making sense of Corporate Social Responsibility: Exploring organizational processes and strategies. J. Clean. Prod. 2010, 18, 1787-1796. [CrossRef]

94. Alänge, S.; Clancy, G.; Marmgren, M. Naturalizing sustainability in product development: A comparative analysis of IKEA and SCA. J. Clean. Prod. 2016, 135, 1009-1022. [CrossRef]

95. Ali, F.; Verhulst, E.; Boks, C. The "Nordic Approach" and how it may support design for sustainability. In Proceedings of the NordDesign 2016, Trondheim, Norway, 10-12 August 2016; Volume 1.

96. Courage, C.; Baxter, K. Understanding Your Users: A Practical Guide to User Requirements Methods, Tools, and Techniques; Gulf Professional Publishing: Houston, TX, USA, 2005; ISBN 9781558609358.

97. Ali, F.; Boks, C.; Stewart, R.; Bey, N. Company personas as a tool for improved Design for Sustainability implementation. In preparation.

98. Ali, F.; Boks, C. An exploration of company personas to support customized DfS implementation. In Proceedings of the 21st International Conference on Engineering Design (ICED 17) Vol 5: Design for $X$, Design to X, Vancouver, BC, Canada, 21-25 August 2017.

99. Gray, D.E. Facilitating management learning: Developing critical reflection through reflective tools. Manag. Learn. 2007, 38, 495-517. [CrossRef]

(C) 2018 by the authors. Licensee MDPI, Basel, Switzerland. This article is an open access article distributed under the terms and conditions of the Creative Commons Attribution (CC BY) license (http:/ / creativecommons.org/licenses/by/4.0/). 